\title{
ABIOTIC STRESS AND BIOFERTILIZER ON THE Pereskia bleo (Kunth) DC. AGAINST GROWTH, PROLINE, AND ANTIOXIDANT
}

\author{
Intan Christin Dullah ${ }^{1 *}$, Sulandjari ${ }^{2}$, and Supriyono ${ }^{2}$ \\ ${ }^{1}$ Post Graduate Student of Agronomy, Sebelas Maret University, Surakarta, Central Java 57126, \\ Indonesia \\ ${ }^{2}$ Departement of Agrotechnology, Faculty of Agriculture, Sebelas Maret University \\ Submitted : 2018-11-06 Accepted : 2018-12-28
}

\begin{abstract}
Pereskia bleo is a spiny bush from the genus Pereskia and family Cactaceae. Its leaves are shiny green, flowering and fruitful. Some researchers were indicated that $P$.bleo leaves contain high antioxidants, anti-cancer, treat diabetes, hemorrhoids, hypertension, and gastric pain. The purpose of this study is to investigate the effects of abiotic stress and intake of biofertilizers on growth, proline, and antioxidants. The experiment was arranged using the nested design (complete random factorial) with three treatments. the first treatment of sodium chloride with three levels is; $0 \mathrm{ppm}, 5 \mathrm{ppm}, 10 \mathrm{ppm}$ and the treatment of the two biofertilizers with two levels is; $5 \mathrm{ppm}, 10 \mathrm{ppm}$. One and two treatments nested in treatment three were $500 \mathrm{ml}, 300 \mathrm{ml}$, and $150 \mathrm{ml}$ water volume per polybag. Each treatment was repeated three times, resulting in a total sample of 54 plants. The findings indicate that abiotic pressure suppressed growth and chlorophyll, while the proline tended to decrease. Abiotic stress can increase the antioxidant content and promote the interaction between salinity and biofertilizer against antioxidants.
\end{abstract}

Keywords: Biofertilizer, Drought stress, Pereskia bleo, Salinity, Secondary metabolites

How to Cite: Dullah, I.C., Sulandjari, and Supriyono. (2019). Abiotic Stress and Biofertilizer on the Pereskia bleo (Kunth) DC. Against Growth, Proline, and Antioxidant. Sains Tanah Journal of Soil Science and Agroclimatology, 16(1): 36-45 (doi: 10.20961/stjssa.v16i1.25158)

Permalink/DOI: http://dx.doi.org/10.20961/stjssa.v16i1.25158

\section{INTRODUCTION}

Pereskia, family Cactaceae originates from America and is distributed in tropical and subtropical regions. The genus has 17 species including Pereskia bleo, Pereskia. Grandifolia and Pereskia. acuelata (Zareisedehizadeh et al., 2014). Pereskia is a spiny, shrubby, and leafy plant. The leaves of, this plant are simple, spiral, glossy and succulent (Wiart, 2006). The flowers are yellow to red and the ripe fruit is yellow, a fleshy, cone-shaped and contains seeds (Zareisedehizadeh et al., 2014). The ingredients

\footnotetext{
* Corresponding Author:

Email: intanchristin0@gmail.com
}

of phytochemicals active Pereskia bleo include alkaloids, flavonoids, catechins, $\beta$ carotene and high antioxidants (Tan et al., 2005). In Malaysia, China and Indians in America, Pereskia bleo leaves are traditionally used for the treatment of cancer, hypertension, diabetes and other diseases. In addition to the treatment of leaves, Pereskia bleo is also used as a vegetable because it contains many minerals (Malek et al., 2009; Murillo et al., 2010). Drought can be caused by water, that- available in the soil which is reduced and or high evapotranspiration so that plants lose turgor pressure. In addition, salinity also causes 
drought stress, among others, because of the high salt content in soil solution where rainfall is not able to dissolve it so that the potential of water in the medium grows low and ionic poisoning due to excessive uptake of sodium and chloride ions (Jamil et al., 2007).

Environmental stress affects the growth of plants such as drought and high salinity. These environmental pressure have the potential to reduce crop productivity. High salinity causes a decrease in water potential and affects the availability of water and also reduces nutrient uptake (Hussain et al., 2009). Water deficit and salinity of the plant can be seen the signs on the growth and physiological responses. So, we can consider the tolerance ability of a plant to drought and salinity. Drought results in germination inhibited, vegetative and generative growth is depressed. Salinity also affects photosynthesis, further suppress leaf area, chlorophyll content and stomatal closure. For example, in Mentha piperita L (Tabatabaie \& Nazari, 2007), Catharanthus (Jaleel et al., 2008) and Thymus vulgaris $L$ (Aziz et al., 2008). The challenge of environmental stress is not only for food crops but also for medicinal plants. But with secondary metabolite productivity, abiotic stress is not always the result of decrease, as evidenced by some studies proving that abiotic stress conditions raise the secondary metabolite levels of medicinal plants.

Damage to plants due to salinity mainly through the effects of osmosis, certain ionic toxicity, and nutritional stress. Proline is one of the amino acids that play a role in the tolerance of plants against abiotic stress. In Echium amoeum medicinal plants increased salinity has increased proline levels even though the dry weight of the root's decreases (Ashraf \& Orooj, 2006). Salinity stress was shown to increase proline levels and antioxidant (Munns \& Tester, 2008). Biochemical and physiological responses to drought and salinity stress in plants include inhibition of growth and reduced enzymatic activity and biochemical constituents (Jaleel \& Gopi, 2007). One of the plant's biochemical responses to salt stress is the production of reactive oxygen forms (ROS) that disrupt the balance between ROS production and loss of effect by antioxidant enzymes which cause oxidative damage to lipids, proteins, and nucleic acids (Nayyar \& Gupta, 2006). Antioxidants consist of enzymes including catalase, ascorbate peroxidase, glutathione, ascorbate, total carotenoids, phenolics and flavonoids (Taïbi et al., 2016). Increased antioxidant activity is in line with the increase in enzymes. Some researchers stated that drained stress resistance has worked with increased antioxidant activity (Reddy et al., 2004). Yazici et al. (2007) reported that there has been an increase in enzyme antioxidant activity and proline accumulation in saline conditions.

Biofertilizer is a natural fertilizer that contains many microorganisms that can help improve plant growth and yield. Thus, the biological fertilizer is also believed to increase soil fertility. Therefore, the volume of watering, Sodium Chloride $(\mathrm{NaCl})$, and biological fertilizer in experimental plants in Biofertilizer is a natural fertilizer that contains many microorganisms that can help improve plant growth and yield (Bhardwaj et al., 2014). Thus, the biological fertilizer is also believed to increase soil fertility. Therefore, the volume of watering, salinity, and biological fertilizer in experimental plants in this study is intended to investigate the effect of abiotic pressure and biological fertilizers on growth, proline, and antioxidant of Pereskia bleo.

\section{MATERIALS AND METHODS}

The research was conducted in August 2017-February 2018 in the greenhouse of the Faculty of Agriculture at Sebelas Maret University, Surakarta. Pereskia bleo seedlings 
that have been propagated by means of stem cuttings were used as planting materials. Pereskia bleo was grown in polybags that contained $5 \mathrm{~kg}$ of media consisting $2: 1$ soil and manure ratio.

The experimental was arranged using Nested design (completely randomized factorial) with $\mathrm{NaCl}$ treatment; 0 ppm, $5 \mathrm{ppm}$, 10 ppm, and biofertilizer; 5 ppm, 10 ppm, each nested in a watering volume (below field capacity) of $500 \mathrm{ml}, 300 \mathrm{ml}$ and $150 \mathrm{ml}$ per polybag. Watering was done according to treatment watering once every three days according to the watering volume. Each treatment was repeated three times, resulting in a total sample of 54 plants. Parameter variables to plant height, number of leaves, leave area root and shoot; chlorophyll $a, b$ and total; proline and antioxidants. Chlorophyll analysis by spectrophotometer method; Proline with the ninhydrin method (Bates et al., 1973), and antioxidants by Diphenylpicrylhydrazyl method.

The extraction and estimation of the chlorophyll were done by grounding one gram of finely cut leaf sample with $80 \%$ acetone, then centrifuged. The supernatant is transferred. The absorbance of the solution was read at $645 \mathrm{~nm}$ against the solvent $(80 \%$ acetone) as blank. The concentrations of chlorophyll a, chlorophyll b and total chlorophyll were then calculated using the equation as follows:

Chlorophyll a $(\mathrm{mg} / \mathrm{g})=12.72(\mathrm{OD} 663)-$ 2.59(OD645)

Chlorophyll b (mg/g) = 22.9(OD 645) - (OD 663) Total Chlorophyll $(\mathrm{mg} / \mathrm{g})=20.31($ OD 645) + 8.05(OD 663)

Proline analysis was performed according to Bates et al. (1973; Marin et al., 2009), where diethyl ether extract was exempted from this test since proline is practically insoluble in diethyl ether. $50 \mathrm{mg}$ of extract were homogenized in $10 \mathrm{ml}$ sulphosalicylic acid $(3 \% \mathrm{w} / \mathrm{v})$ and filtrated through filter paper. Two milliliters of the filtrate was mixed with $2 \mathrm{ml}$ of acid ninhydrin solution (1.25 g ninhydrin $+30 \mathrm{ml}$ glacial acetic acid $+20 \mathrm{ml} 6 \mathrm{M} \mathrm{H}_{3} \mathrm{PO}_{4}$ ) and $2 \mathrm{ml}$ of glacial acetic acid and kept at $+100^{\circ} \mathrm{C}$ for $1 \mathrm{~h}$. The reaction was stopped by transferring the mixture to an ice bath. Four milliliters of toluene was added to the mixture and vortexed for 15-20 s. The toluene phase was aspirated and absorbance was measured using pure toluene as a reference (Marin et al., 2009). A calibration curve was prepared with pure proline.

Radical scavenging activity of plant extracts against 2,2-diphenyl-1-picrylhydrazyl (DPPH) radical was determined by spectrophotometrically (Molyneux, 2004). The principle of the assay is based on the color change of the DPPH solution from purple to yellow as the radical is quenched by the antioxidant. Briefly, $1 \mathrm{ml}$ of $0.1 \mathrm{mM}$ DPPH in ethanol was mixed with $3 \mathrm{ml}$ of extract solution with differing concentrations $(5-250 \mathrm{~g} / \mathrm{ml}$ ) and the mixture was vortexed. The samples were kept in the dark for $30 \mathrm{~min}$ at room temperature and then the decrease in absorbance at $517 \mathrm{~nm}$ was measured. The absorbance of DPPH solution in the absence of plant extract was measured as the control. Ascorbic acid and BHT were used as positive controls. DPPH radical scavenging activity was expressed using the formula: \% DPPH radical scavenging activity $=\left[\left(A_{0}-A_{1}\right) / A_{0}\right]-100$ where $A_{0}$ was the absorbance of the control and $A_{1}$ was the absorbance of the sample.

\section{RESULTS}

Soil fertility level on planting medium in this research has low level indicated by organic content $1.89 \%$ (low); $\mathrm{pH} \mathrm{H}_{2} \mathrm{O} 7.4$ (Neutral); Nitrogen available $0.26 \%$ (intermediate); available Phosphorus $8.38 \%$ (intermediate); 
available Potassium 0.24 me\% (Low); and cation exchange capacity $16 \mathrm{me} \%$ (low).

Table 1 shows that the watering volume has a significant or very significant effect on the growth components, namely plant height, leaf number, leaf area, and root-shoot ratio. Meanwhile, the salinity in the watering volume has a very significant effect on the growth component except for plant height. All treatments have no significant effect on chlorophyll and proline, even though it has a very significant effect on antioxidants. There is an interaction between salinity and biofertilizer in the watering volume to antioxidants.

Table 2 shows that in all treatments there was pressure on plant height even though it was not statistically significant. The treatment of $10 \mathrm{ppm} \mathrm{NaCl}$ at $150 \mathrm{ml}$ watering volume produced the lowest plant height compared to the above watering volume.
Salinity and drought stress results in a reduced number of leaves and leaf area. The treatment of $10 \mathrm{ppm} \mathrm{NaCl}$ at the $150 \mathrm{ml}$ watering volume produced the least number of leaves and the lowest leaf area. Salinity and drought stress suppress the ratio of shoot roots, treatment of $10 \mathrm{ppm} \mathrm{NaCl}$ at $150 \mathrm{ml}$ watering volume produces the lowest root canopy ratio. Salinity and drought stress suppress the components of chlorophyll a, chlorophyll $b$ and total chlorophyll, although they are not statistically significant.

In this research, all treatments did not significantly affect the proline content (Table 1). Table 3 shows that the treatment of $10 \mathrm{ppm}$ biofertilizer and $10 \mathrm{ppm} \mathrm{NaCl}$ decreases the proline content in each watering volume, even though it is not statistically significant. On the other hand, Figure 1 depicts the higher level of stress promoted the higher antioxidant contents.

Table 1. Analysis of variance in the effect of salinity and biofertilizer in watering volume on growth, proline, and antioxidants

\begin{tabular}{lccccccccc}
\hline Source & $\begin{array}{c}\text { Plant } \\
\text { high }\end{array}$ & $\begin{array}{c}\text { Leaf } \\
\text { number }\end{array}$ & $\begin{array}{c}\text { Leaf } \\
\text { area }\end{array}$ & $\begin{array}{c}\text { Root- } \\
\text { shoot } \\
\text { ratio }\end{array}$ & $\begin{array}{c}\text { Chlorophyll Chlorophyll } \\
\mathbf{a}\end{array}$ & $\begin{array}{c}\text { Total } \\
\text { chlorophyll }\end{array}$ & Proline Antioxidant \\
\hline $\mathrm{W}$ & $* *$ & $* *$ & $* *$ & $*$ & $\mathrm{~ns}$ & $\mathrm{~ns}$ & $\mathrm{~ns}$ & $\mathrm{~ns}$ & $* *$ \\
\hline $\mathrm{S}$ & $\mathrm{ns}$ & $* *$ & $* *$ & $* *$ & $\mathrm{~ns}$ & $\mathrm{~ns}$ & $\mathrm{~ns}$ & $\mathrm{~ns}$ & $* *$ \\
\hline $\mathrm{B}$ & $\mathrm{ns}$ & $\mathrm{ns}$ & $\mathrm{ns}$ & $\mathrm{ns}$ & $\mathrm{ns}$ & $\mathrm{ns}$ & $\mathrm{ns}$ & $\mathrm{ns}$ & $* *$ \\
\hline $\mathrm{S} * \mathrm{~B}$ & $\mathrm{~ns}$ & $\mathrm{~ns}$ & $\mathrm{~ns}$ & $\mathrm{~ns}$ & $\mathrm{~ns}$ & $\mathrm{~ns}$ & $\mathrm{~ns}$ & $\mathrm{~ns}$ & $* *$ \\
\hline
\end{tabular}

Note: $\mathrm{W}=$ Watering volume; $\mathrm{S}=$ Salinity; $\mathrm{B}=$ Biofertilizer; $\mathrm{S}{ }^{*} \mathrm{~B}=$ Interaction; ${ }^{* *}=$ very significant ;

* = significant; ns= not significant 
Table 2. Effect of salinity and biofertilizer in watering volumes on growth component

\begin{tabular}{|c|c|c|c|c|c|}
\hline \multirow{3}{*}{ Parameter } & \multicolumn{5}{|c|}{ Treatment } \\
\hline & \multirow{2}{*}{ Watering } & \multicolumn{3}{|c|}{ Salinity $\mathrm{NaCl}$ (ppm) } & \multirow[b]{2}{*}{ Average } \\
\hline & & 0 & 5 & 10 & \\
\hline \multirow[t]{3}{*}{ Plant high $\left(\mathrm{cm}^{2}\right)$} & $500 \mathrm{ml}$ & 62.40 & 62.23 & 63.37 & $62.67^{P}$ \\
\hline & $300 \mathrm{ml}$ & 56.75 & 54.62 & 59.93 & $57.09^{Q}$ \\
\hline & $150 \mathrm{ml}$ & 53.78 & 56.08 & 57.08 & $55.65^{R}$ \\
\hline \multirow[t]{3}{*}{$\begin{array}{c}\text { Number of } \\
\text { leaves }\end{array}$} & $500 \mathrm{ml}$ & $62.67^{\mathrm{a}}$ & $83.67^{a}$ & $58.50^{b}$ & $68.28^{P}$ \\
\hline & $300 \mathrm{ml}$ & $58.50^{b}$ & $51.33^{b}$ & $77.67^{\mathrm{ab}}$ & $62.50^{Q}$ \\
\hline & $150 \mathrm{ml}$ & $40.33^{b c}$ & $36.67^{c}$ & $35.00^{c}$ & $37.33^{R}$ \\
\hline \multirow[t]{3}{*}{ Leaf area $\left(\mathrm{cm}^{2}\right)$} & $500 \mathrm{ml}$ & $0.43^{a}$ & $0.31^{b}$ & $0.29^{b c}$ & $0.24^{P}$ \\
\hline & $300 \mathrm{ml}$ & $0.34^{\mathrm{b}}$ & $0.26^{\mathrm{bc}}$ & $0.25^{b c}$ & $0.28^{P}$ \\
\hline & $150 \mathrm{ml}$ & $0.09^{c}$ & $0.07^{b c}$ & $0.06^{c}$ & $0.08^{Q}$ \\
\hline \multirow[t]{3}{*}{$\begin{array}{l}\text { Root Shoot } \\
\text { Ratio }\end{array}$} & $500 \mathrm{ml}$ & $0.23^{\mathrm{a}}$ & $0.17^{b}$ & $0.21^{\mathrm{a}}$ & $0.20^{P}$ \\
\hline & $300 \mathrm{ml}$ & $0.22^{\mathrm{a}}$ & $0.18^{b}$ & $0.13^{c}$ & $0.18^{Q}$ \\
\hline & $150 \mathrm{ml}$ & $0.19^{c}$ & $0.17^{b}$ & $0.17^{b}$ & $0.17^{Q}$ \\
\hline \multirow[t]{3}{*}{ Chlorophyll a } & $500 \mathrm{ml}$ & 13.94 & 10.85 & 11.70 & 12.16 \\
\hline & $300 \mathrm{ml}$ & 12.31 & 11.42 & 10.32 & 11.35 \\
\hline & $150 \mathrm{ml}$ & 11.40 & 9.61 & 9.55 & 10.19 \\
\hline \multirow[t]{3}{*}{ Chlorophyll b } & $500 \mathrm{ml}$ & 4.53 & 4.17 & 4.66 & 4.45 \\
\hline & $300 \mathrm{ml}$ & 4.52 & 5.74 & 3.78 & 4.68 \\
\hline & $150 \mathrm{ml}$ & 5.09 & 3.70 & 3.91 & 4.23 \\
\hline \multirow{3}{*}{$\begin{array}{c}\text { Total } \\
\text { Chlorophyll }\end{array}$} & $500 \mathrm{ml}$ & 19.12 & 14.61 & 16.09 & 16.61 \\
\hline & $300 \mathrm{ml}$ & 17.11 & 15.49 & 14.11 & 15.57 \\
\hline & $150 \mathrm{ml}$ & 16.50 & 13.22 & 13.47 & 14.40 \\
\hline
\end{tabular}

Notes: Numbers followed by the same letter (a-c) in columns and rows or (P-R) in the column, each parameter shows no significant difference in $1 \%$ or $5 \%$ DMRT test

Table 3. Effects of salinity and biofertilizer nested in the watering volume on proline content

\begin{tabular}{ccccc}
\hline Watering & Biofertilizer & $\mathbf{0 ~ p p m ~ N a C l}$ & $\mathbf{5} \mathbf{~ p p m ~} \mathbf{~ N a C l}$ & $\mathbf{1 0} \mathbf{~ p p m ~} \mathbf{~ a C l}$ \\
\hline $500 \mathbf{m l}$ & 5 ppm bio & 2.45 & 0.35 & 1.05 \\
& 10 ppm bio & 0.6 & 0.53 & 0.73 \\
\hline \multirow{2}{*}{$300 \mathrm{ml}$} & 5 ppm bio & 1.04 & 0.38 & 0.06 \\
& 10 ppm bio & 0.64 & 0.78 & 0.45 \\
\hline \multirow{2}{*}{$150 \mathrm{ml}$} & 5 ppm bio & 1.19 & 0.85 & 1.35 \\
& 10 ppm bio & 0.02 & 0.44 & 0.46 \\
\hline
\end{tabular}




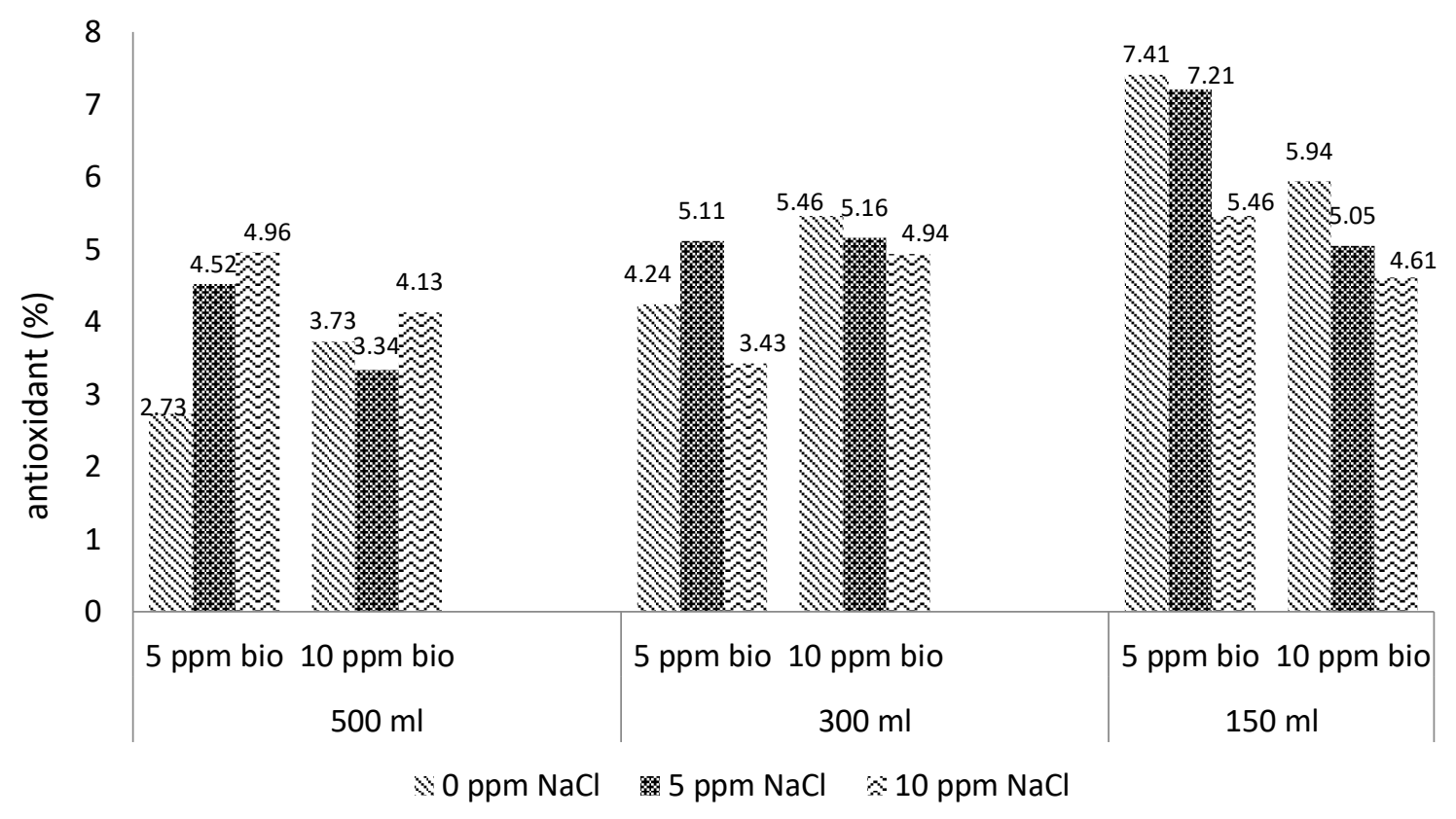

Figure 1. Histogram of biofertilizer and salinity interaction at several watering volume levels of antioxidant content

\section{DISCUSSION}

Abiotic stress includes drought and salinity is one of the important factors that affect every aspect of growth and crop production. These stresses cause water to be unavailable in the root area so that the absorption of water and nutrients for the metabolism of the plant becomes disrupted. Kannan \& Kulandaivelu (2011) stated that the availability of nutrients in growing media influence on plant growth. However, drought stress from lack of water or productivity can affect the active ingredients of the plant.

Table 2 shows that drought has negatively affected growth. The watering volume of $300-150 \mathrm{ml}$ was significantly different from the adequacy of water as much as $500 \mathrm{ml}$. Water potential is lower due to drought stress, hence the cell enlargement and generative process will be depressed. Cell growth decreases in response to plants facing drought stress due to inhibited cell development and cell turgor pressure. Turgor cells decrease resulting in stunted growth and enlargement of leaves. Therefore, in this study drought caused the number of leaves and leaf area to be depressed, plant biomass also decreased so that the root-shoot ratio decreased as the plant response mechanism avoided the magnitude of transpiration and water absorption activities. The research of (Bhardwaj et al., 2014) showed that drought stress suppressed plant height, number of leaves and root dry weight. Drought also inhibits plant growth and development due to the inhibition of cell division and closing of the stomata.

Salinity suppresses growth components except for plant height. The higher the concentration of $\mathrm{NaCl}$, the more suppressed the growth will be. So that plant height, leaf number, leaf area and root-shoot ratio at 150 $\mathrm{ml}$ watering volume were significantly lower than larger watering volumes. $\mathrm{NaCl}$ can cause a decrease in osmosis pressure which causes plants to have difficulty absorbing water. This 
will reduce the rate of photosynthesis because the stomata close and decrease cell turgor which is reflected in a decrease in the number of leaves and leaf area (Xu \& Zhou, 2008).

Chlorophyll content is one of the indicators used to determine the response of plants to drought and salinity stress (Ai \& Banyo, 2011). Table 1 shows that drought stress has no significant effect on chlorophyll a, chlorophyll b and total chlorophyll. However, the analysis of chlorophyll content was different between treatments, the higher the stress level the lower the chlorophyll content produced (Table 2). Water availability is an important factor in the process of chlorophyll formation (Alonso et al., 2002). In this study, drought and salinity produced a decreased chlorophyll content in Pereskia bleo plants according to several studies including Ambede et al. (2012) and Keyvan (2010), who examined the effect of salinity and dryness on chlorophyll content in ginger and wheat plants which showed a decrease in chlorophyll content. The stress of drought and salinity stress increases osmotic pressure and Reactive Oxygen Species (ROS) content in plants that can cause cell damage so that the biochemical processes of photosynthesis in plants will be hampered (Ambede et al., 2012).

Proline accumulation is an indicator of the plant's response to abiotic stresses, especially drought and salinity. Some studies report that proline accumulation is lower in tolerant plants than in plants that are sensitive to salinity stress and drought (Jungklang et al., 2017). Proline is a compound that includes amino acids that can be used to show the plant's response to stress in drought and salinity (Li et al., 2018). Each plant produces a different proline content, this is because the characteristics indicate that drought stress, salinity, and biological fertilizers do not significantly affect the proline content (Table 1). However, the analysis of the proline content was different between treatments, the higher the stress level the lower the proline content produced. This is due to the provision of biofertilizers to plants that provide nutrients for plants to keep plants remain tolerant. Plant defense mechanisms against stress are carried out with morphological and physiological adaptations (Mathius et al., 2004)

Antioxidants consist of enzymes including catalase, ascorbic peroxidase, glutathione, ascorbate, total carotenoids, phenolics and flavonoids (Taïbi et al., 2016). Increased formation and activity of the antioxidants indicates stressful plants (Agati et al., 2012). A higher level of stress accompanied with a higher the antioxidant observed in Figure 1 is in line with the research of Abdillah et al. (2015) regarding the effect drought Stress on antioxidant content in sorghum plants showing that increased antioxidant content as a mechanism of defense and tolerance to drought. This increase in antioxidant activity is consistent with the increase in enzymes. Stressful plants respond with the production of a form of reactive oxygen (ROS) that disrupts the balance between the production of ROS and the loss of effects by antioxidant enzymes that cause oxidative damage to lipids, proteins and nucleic acids with a consequence of increase antioxidants. Plant growth booster Rhizobacteria (PGPR) contained in biofertilizers can increase plant resistance to drought and salinity (Yang et al., 2009). The bacteria contained in biofertilizers help root development by increasing root surface area and the number of root tips, to provide nutrients for plants during stressful conditions (Yang et al., 2009).

\section{CONCLUSION}

This study shows that abiotic pressure suppressed growth, whereas chlorophyll and proline decreased. There was an interaction between salinity and biofertilizer towards 
antioxidants. $10 \mathrm{ppm} \mathrm{NaCl}$ in $150 \mathrm{ml}$ water volume produced the lowest growth, while 0 ppm $\mathrm{NaCl}$ and $5 \mathrm{ppm}$ biofertilizer in $150 \mathrm{ml}$ water resulted in the highest antioxidant. Further research by examining the balanced salinity, drought, and biofertilizer concentrations to get high yields with high antioxidant content is necessary.

\section{REFERENCES}

Abdillah, D., Siswoyo, T. A., \& Soedradjad, R. (2015). Pengaruh Cekaman Kekeringan Terhadap Kandungan Fenolik dan Antioksidan Tanaman Sorgum (Sorghum bicolor L. Moench) pada Fase Awal Vegetatif. Berkala Ilmiah Pertanian, 1(1), 1-4.

Agati, G., Azzarello, E., Pollastri, S., \& Tattini, M. (2012). Review Flavonoids as Antioxidants in Plants: Location and Functional Significance. Plant Science, 196, 67-76. 10.1016/j.plantsci.2012.07.014

Ai, S. N., \& Banyo, Y. (2011). Kosentrasi Klorofil Daun Sebagai Indikator Kekurangan Air pada Tanaman. Jurnal IImiah Sains, 11(2), 166-173. 10.1234/jis.v11i2.202u

Alonso, M., Rozados, M. J., Vega, J. A., PerezGorostiaga, P., Cuinas, P., Fonturbel, M. T., \& Fernandes, C. (2002). Biochemical Responses of Pine Pinaster Treesto FireInduced Trunk Girdling and Crown Scorch: Secondary Metabolites and Pigments as Needle Chemical Indicators. Journal of Chemical Ecology, 28(4), 687-700.

Ambede, J. G., Godffrey, W. N., Gideon, G. M., \& David, M. M. (2012). NaCl Salinity Affects Germination, Growth, Physiology, and Biochemistry of Bambara Groundnut. Brazilian Journal of Plant Physiology, 24(3). 10.1590/S167704202012000300002

Ashraf, M., \& Orooj, A. (2006). Salt Stress Effects on Growth, Ion Accumulation and Seed Oil Concentration in Anarid Zone Traditional Medicinal Plant Ajwain (Trachyspermum ammi [L.] Sprague). Journal of Arid Environments, 64(2), 209220. 10.4236/ajps.2017.88121
Aziz, E. E., Al-Amier, H., \& Craker, L. E. (2008). Influence of Salt Stress on Growth and Essential Oil Production in Peppermint, Pennyroyal, and Apple Mint. Journal of Herbs, Spices \& Medicinal Plants, 14(1-2), 77-87. 10.1080/10496470802341375

Bates, L. S., Waldren, R. P., \& Teare, I. D. (1973). Rapid Determination of Free Proline for Water Stress Studies. Plant Soil, 39(1), 205-207. 10.1007/BF00018060

Bhardwaj, D., Ansari, M. W., Sahoo, R. K., \& Tuteja, N. (2014). Biofertilizers Function as Key Player in Sustainable Agriculture by Improving Soil Fertility, Plant Tolerance, and Crop Productivity. Microbial Cell Factories, 13(66). 10.1186/1475-285913-66

Hussain, K., Majeed, A., Nawaz, K., Khizar, H. B., \& Nisar, M. F. (2009). Effect of Different Levels of Salinity on Growth And Ion Contents of Black Seeds (Nigella sativa L.). Current Research Journal of Biological Sciences, 1(3), 135-138.

Jaleel, C. A., Sankar, B., Sridharan, R., \& Panneerselvam, R. (2008). Soil Salinity Alters Growth, Chlorophyll Content, and Secondary Metabolite Accumulation in Catharanthus roseus. Turkish Journal of Biology, 32(2), 79-83.

Jaleel, C., \& Gopi, R. (2007). Responses of Antioxidant Defense System of Catharanthus roseus (L.) G. Don. to Paclobutrazol Treatment Under Salinity. Acta Physiologiae Plantarum, 29(3), 205209.

Jamil, M., Rehman, S., Lee, K. J., Kim, J. M., Kim, H. S., \& Rha, E. S. (2007). Salinity Reduced Growth PS II Photochemistry and Chlorophyll Content in Radish. Scientia Agricola, 62(2), 111-118.

Jungklang, J., Saengnil, K., \& Uthaibutra, J. (2017). Effects of Water-Deficit Stress and Paclobutrazol on Growth, Relative Water Content, Electrolyte Leakage, Proline Content and Some Antioxidant Changes in Curcuma alismatifolia Gagnep. cv. Chiang Mai Pink. Saudi Journal of Biological Sciences, 24(7), 1505-1512. 10.1016/j.sjbs.2015.09.017

Kannan, N. D., \& G. Kulandaivelu. (2011). Drought Induced Changes in 
Physiological, Biochemical and Phytochemical Properties of Withania somnifera. Journal of Medicinal Plants Research, 5(16), 3929-3935.

Keyvan, S. (2010). The Effects of Drought Stress on Yield, Relative Water Content, Proline, Soluble Carbohydrates and Chlorophyll of Bread Wheat Cultivars. Journal of Animal \& Plant Sciences, 8(3), 1051-1060.

Li, J., Yaling, W., Juanjuan, W., Yu, P., Chenggang, S., \& Xiangguo, Z. (2018). A Tomato Proline-, Lysine-, And GlutamicRich Type Gene SpPKE1 Positively Regulates Drought Stress Tolerance. Biochemical and Biophysical Research Communications, 499(4), 777-782. 10.1016/j.bbrc.2018.03.222

Malek, S. N., Shin, S. K., Wahab, N. A., \& Yaacob, H. (2009). Cytotoxic Components of Pereskia bleo (Kunth) DC. (Cactaceae) Leaves. Molecules, 14(5), 1713-1724. $10.1155 / 2011 / 368692$

Marin, J. A., Andreu, P., Carrasco, A., \& Arbeloa, A. (2009). Prolina en Tejidos y Exudados de Raíz Como Respuesta Al Estrés Salino de Cultivos de Raíces Aisladas de Patrones Frutales Del Género Prunus. ITEAInformación Técnica Económica Agraria, 105(4), 282-290.

Mathius, N. T., Liwang, T., Danuwikarsa, M. I., Suryatmana, G., Djajasukanta, H., Saodah, D., \& Astika, I. G. W. (2004). Respon Biokimia Beberapa Progeni Kelapa Sawit (Elaeis guineensis Jacq.) terhadap Cekaman Kekeringan pada Kondisi Lapang. Menara Perkebunan Indonesian Journal of BiotecHnology Research and Estate, 72(2), 38-56.

Molyneux, P. (2004). The Use of The Stable Free Radical Diphenylpicrylhydrazyl (DPPH) for Estimating Antioxidant Activity. Songklanakarin Journal of Science and Technology, 26(2), 211-219.

Munns, R., \& Tester, M. (2008). Mechanisms of Salinity Tolerance. Annual Review of Plant Biology, 59, 651-681.

Murillo, E. A., Mel'endez-Mart'ınez, J., \& Portugal, F. (2010). Screening of Vegetables and Fruits from Panama for Rich Sources of Lutein and Zeaxanthin. Food Chemistry, 122(1), 167-172. 10.1016/j.foodchem.2010.02.034

Nayyar, H., \& Gupta, D. (2006). Differential Sensitivity of C3 and C4 Plants to Water Deficit Stress: Association with Oxidative Stress and Antioxidant. Environmental and Experimental Botany, 58(1-3), 106113. 10.1016/j.envexpbot.2005.06.021

Reddy, A. R., Chiatanya, K. V., \& Vivekanandan, M. (2004). Drought Induced Responses of Photosynthesis and Antioxidant Metabolism in Higher Plants. Journal of Plant Physiology, 161(11), 1189-1202. 10.1016/j.jplph.2004.01.013

Tabatabaie, S. J., \& Nazari, J. (2007). Influence of Nutrient Concentration and $\mathrm{NaCl}$ Salinity on Growth, Photosynthesis and Essential Oil Content Of Peppermint And Lemon Verbena. Turkish Journal of Agriculture and Forestry, 31(4), 245-253.

Taïbi, K., Fadhila, T., Leila, A. A., Amel, E., Moulay, B., \& José, M. (2016). Effect of Salt Stress on Growth, Chlorophyll Content, Lipid Peroxidation and Antioxidant Defence Systems in Phaseolus vulgaris L. South African Journal of Botany, 105, 306-312. 10.1016/j.sajb.2016.03.011

Tan, M. L., Sulaiman, S. F., Najmuddin, N., Samian, M. R., \& Muhamad, T. S. (2005). Methanolic Extract of Pereskia bleo (Kunth) DC. (Cactaceae) Induces Apoptosis in Breast Carcinoma, T47-D cell line. Journal of Ethnopharmacology, 96(1-2), 287-294. 10.1016/j.jep.2004.09.025

Wiart, C. (2006). Medicinal plants of the AsiaPasifik: drugs for the future. Singapore: World Scientific. 10.1142/5834

Xu, Z., \& Zhou, G. (2008). Response of Leaf Stomatal Density to Water Status and Hs Relationship with Photosynthesis in Agrass. Journal of Experimental Botany, 59(12), 3317-3325.

Yang, J., Kloepper, J. W., \& Ryu, C. M. (2009). Rhizosphere Bacteria Help Plants Tolerate Abiotic Stress. Trends in Plant Science, 14(1), 1-4.

Yazici, I., Turkan, I., Sekmen, A. H., \& Demiral, T. (2007). Salinity Tolerance of Purslane (Portulaca oleracea L.) is Achieved by Enhanced Antioxidative System, Lower 
Level of Lipid Peroxidation, and Proline Accumulation. Environmental and Experimental Botany, 61(1), 49-57. 10.1016/j.envexpbot.2007.02.010

Zareisedehizadeh, S., Tan, C.-H., \& Koh, H.-L. (2014). A Review of Botanical
Characteristics, Traditional Usage, Chemical Components, Pharmacological Activities and Safety of Pereskia bleo (Kunth) DC. Evidence-Based Complementary and Alternative Medicine, 2014. 10.1155/2014/326107 